\title{
PREPARATION FOR THE ENERGY ACT 2011 AND MINIMUM ENERGY EFFICIENCY STANDARDS IN UK COMMERCIAL PROPERTY
}

\author{
Emma MULLINER a,*, Louise KIRSTEN b \\ a School of the Built Environment, Liverpool John Moores University, Byrom Street, Liverpool L33AF, UK \\ ${ }^{b}$ Department of the Natural and Built Environment, Sheffield Hallam University, City Campus Howard \\ Street, Sheffield S1 $1 \mathrm{WB}, \mathrm{UK}$
}

Received 7 September 2015; accepted 11 May 2016

\begin{abstract}
Improving the energy performance of buildings has become a priority area for energy efficiency policy across the European Union. A cornerstone to achieving carbon reductions in UK buildings is the Energy Act 2011 and subsequent minimum energy efficiency standards. This Act contains a number of provisions which will have implications for the commercial property sector. The paper presents a quantitative study that investigates the implications of the legislation and assesses how key stakeholders, specifically commercial landlords and property agents, are preparing for its implementation. The results reveal there is generally a good awareness of the Act and suggest that a number of property owners, and to a lesser extent advisers, are taking greater account of energy and environmental performance in their acquisitive due diligence and asset management strategies, as a result of the Act. Less preparation was evident with regard to green leasing practice, although this was being considered as an action in the near future.
\end{abstract}

KEYWORDS: Energy Act 2011; Commercial property; Energy performance certificates; Minimum energy efficiency standards; Sustainability

SUPPLEMENTARY MATERIAL associated with this article can be found, in the online version, at https://doi.org/10.3846/1648715X.2016.1249534

\section{INTRODUCTION}

Global warming is now a significant and growing concern that governments around the world are seeking to address. The UK government's Climate Change Act 2008 set an ambitious and world first legally-binding target to reduce the UK's greenhouse gas emissions by $80 \%$ by 2050 , from a 1990 baseline (UK Parliament 2008). The built environment accounts for almost $40 \%$ of UK carbon emissions; commercial buildings account for approximately $12 \%$ of such carbon emissions, with the remainder produced by domestic buildings (HM Government 2011b). Accordingly, the vast potential for making carbon reductions in the built environment is widely recognised and it has thus been targeted as a key area for change. However, the commercial property sector has traditionally been perceived as slow to respond to the sustainability agenda (Pivo, McNamara 2005; Cox, Cadman 2000). Accord-

\footnotetext{
* Corresponding author. E-mail: e.k.mulliner@ljmu.ac.uk
}

ingly, intervention from governments and special interest-groups to achieve higher levels of energy efficiency for the sector has increased substantially over the past decade (Chegut et al. 2014).

Across Europe, improving the energy performance of buildings has become a priority area for energy efficiency policy (Lown 2014). This is demonstrated by the introduction of European Union (EU) directives, such as the Energy Performance of Buildings Directive (EPBD) which required all EU countries to enhance their building regulations and to introduce energy certification schemes for buildings. In 2010 the EPBD Recast also introduced a 2020 target obligation for all new buildings to be nearly zero energy buildings (European Parliament and Council of the European Union 2010).

While new buildings are increasingly meeting better sustainability design standards, $99 \%$ of buildings are existing ones and it is estimated that $70 \%$ of today's existing built stock will still be in use in 2050 (Stafford et al. 2011). Accordingly, this 
means that retrofitting, along with better management, operation and use of the existing stock, will be paramount in achieving the required carbon reductions. Since roughly two-thirds of UK commercial property is leased to tenants (Property Industry Alliance 2013), attention needs to be paid to the way in which the landlord and tenant relationship functions (Hinnells et al. 2008). It is crucial that a better understanding is developed of, not only the technical possibilities of buildings, but also of the interplay between the content and structure of leases and the behaviour of the various players involved in letting and utilising the space (Roussac, Bright 2012). Concerns have been made in the past that the government has consistently failed to act with regard to the sustainable management and use of existing buildings (Sayce et al. 2007).

The rate of progress in tackling energy inefficiency in existing commercial stock is still considered too slow (Dixon et al. 2014). However, legislation that specifically catches the existing built stock is now in place in the UK as a result of requirements set out in the EPBD. At the forefront to achieving the UK's carbon reduction target in new and existing buildings is the Energy Act 2011 ("the Act"), which was granted Royal Assent in October 2011 (HM Government 2011a). The Act includes provision for energy efficiency regulations specifically targeted at rented properties in both the domestic and non-domestic sectors. The detail is set out in the Energy Efficiency (Private Rented Property) (England and Wales) Regulations 2015 (the "Regulations") which will make it unlawful for landlords to lease property below a minimum energy efficiency standards (MEES) until it has complied with the obligations to make relevant energy improvements (HM Government 2011a). The minimum energy rating required is set at an Energy Performance Certificate (EPC) rating of 'E', and will come into force by 1 April 2018 in England and Wales (DECC 2014). Accordingly, landlords will not be lawfully permitted to lease any property which has an EPC rating of $F$ or $G$ unless improvements are made or certain exemptions apply. This will initially only be applicable to new leases, including sub-letting, assignments and renewals under the Landlord and Tenant Act 1954. However, from 2023 the rules will also apply to existing commercial leases (DECC 2014). The principal exemption is that energy efficiency improvement works should be economically viable before a building is eligible under the Act. For the non-domestic sector the viability test is that the required improvement works would pay for themselves, via predicted energy bill savings, on a simple seven year payback basis. Further exemptions include short leases of less than six months (where there is no provision to renew or extend) and leases over 99 years. Furthermore, landlords do not have to carry out the improvements if the tenant or a third party consent is required for the works and such consent has been refused or where the works would devalue the market value of the property by $5 \%$ (DECC 2014). Certain buildings are also expected to be exempt from the regulations, such as listed buildings where their character would be unacceptably altered if improvements were made.

It has been suggested that $18 \%$ of UK commercial stock has EPC ratings of 'F' or 'G', while a further $20 \%$ are rated 'E' (GVA 2014). However, additional research warns that the number of noncompliant properties could increase if EPCs are updated to take into account changes that have been made to the calculation methodology in the last few years (Lown 2014). Consequently, sustainability should no longer be a minor consideration for commercial property owners and investors. The Act could have far reaching implications for the commercial property sector. As a result, it is estimated that commercial landlords in England and Wales could face a $£ 29$ billion bill to bring their properties up to legal energy efficiency standards by 2018 (Estates Gazette 2014). Aside from the financial cost of upgrading properties, the Regulations could have major implications on the marketability of certain properties with low EPC ratings. This could ultimately impact on their valuation and intensify the possibility of obsolescence in the future. Accordingly, there is a risk that a poor EPC rating may affect the investment value of a property asset. In light of this, EPC ratings are likely to be of increasing concern to property investors as it will be essential to gain an understanding of the energy performance of their stock. While the 2018 deadline may not be within some investors' investment time frames (Elliott et al. 2015), landlords should now be reviewing their property portfolios and, where necessary, considering options for improving energy efficiency ratings prior to 2018 or alternatively considering the disposal of poorly rated stock.

The Energy Act 2011 contains a number of implications for the UK commercial property sector. It is vital that landlords begin to gain an in-depth understanding of the energy performance of their property portfolios and the implications of the Act, in order to mitigate risk and protect asset value. 
However, it is not clear how much progress has been made by the commercial sector in preparation for the aforementioned legislation or what effect such legislation is having on the sector. A qualitative industry study by Segro and CoreNet (2013) investigated the implications of the Act from the perspective of corporate occupiers. The findings generally revealed a low awareness of and little preparation made for the Act. Despite such study there is generally a lack of research in this area, particularly from the perspective of landlords. The purpose of the paper is therefore to investigate the implications of the Act, and assess how stakeholders, specifically commercial landlords and commercial property agents, are preparing for the Act. This will provide an indication of the impact that the legislation is having on key players in the commercial property sector.

\section{METHODOLOGY}

A quantitative framework, in the form of online structured questionnaire surveys, was utilised. Two complimentary surveys were created via Bristol Online Surveys (BOS), one for commercial landlords and one for commercial property agents. Landlords were chosen for the study since the Energy Act 2011 has the potential to have a particular impact on this group. Property agents were surveyed in addition to landlords in order to assess how advisers may be working with their clients with regard to the Act and this allowed for comparison between the views of different key stakeholders. While all research methods have their advantages and disadvantages, questionnaire surveys were deemed more suitable for this research since they offer a number of advantages that qualitative research methods do not possess (Cargan 2007). For example, questionnaires have the ability to gather larger amounts of standardised information across a broader geographical region in comparison to qualitative approaches and they allow for anonymity in responses, which may mean that respondents are more inclined to share their true practice and opinions.

The surveys consisted of background questions (see 3.1), followed by Likert-type scale statements concerning respondents' awareness of the Act, the nature of preparations undertaken for the Act (in relation to general management, investment and lease issues) (see Figs 1-5), and opinions on the impact of the legislation on the commercial property sector (see Figs 6 and 7 in Supplementary material).
The survey was distributed via e-mail to 500 commercial agents and 200 commercial landlords of differing sizes and types, ranging from international organisations to local property companies, across all regions of the UK. A stratified sampling approach was adopted. Internet searches and CoStar database were utilised to establish active commercial agents and landlords in all UK regions, to which the survey link was e-mailed. 42 commercial landlords (21\% response rate) and 67 (13\% response rate) commercial agents participated in the surveys. 40 additional landlords and 35 additional agents viewed, but did not complete, the survey. This may suggest that the survey was too detailed or potentially that respondents did not have enough knowledge of the Act to enable them to complete the survey. The implication of this may be that the findings are more representative of organisations that have some interest in environmental themes.

The data was analysed using descriptive statistics in Excel to report frequencies and make comparisons between agent and landlord responses on complementary survey questions.

\section{RESULTS AND DISCUSSION}

\subsection{Background information}

Respondents in both surveys were asked background questions to establish the type of properties (sectors) they dealt with, the letting structures used, as well as the approximate value of the property portfolios that they were involved with (see Supplementary Appendix A for a table illustrating these results). The majority of landlords (44\%) owned extremely valuable portfolios of over $£ 1$ billion. $20 \%$ of landlords owned portfolios in the region of £1million to $£ 100$ million, $23 \%$ were over $£ 100$ million to $£ 500$ million and $13 \%$ owned portfolios with a value in the region of $£ 500$ million to $£ 1$ billion. Unfortunately, no landlords responded who owned smaller portfolios of less than $£ 1$ million. The authors hypothesis that this lack of participation from smaller landlords could potentially be an indication that smaller organisations have a lack of awareness of the Act and have yet to make significant progress with regard to energy efficiency improvements. Accordingly, it must be noted that the results presented in the subsequent sections are more representative of larger organisations. These results were quite contrasting to the agents, of whom the majority dealt with portfolios under $£ 1$ million (39\%) or between $£ 1$ million to 
$£ 100$ million (42\%). Only $19 \%$ advised on portfolios worth over $£ 100$ million. With regards to the property types/sectors the parties dealt with, both landlords and agents identified that they were involved with a variety of commercial property. However, offices and retail were the dominant sectors in the landlords' portfolios. 97\% of landlords were involved with office property and $87 \%$ with retail, yet fewer were involved with industrial (54\%) and leisure property (49\%). With regard to the agents, $71 \%$ were involved with office property, $74 \%$ with retail, $76 \%$ with industrial and, similar to landlords, fewer were involved with leisure property (48\%). Furthermore, the overwhelming majority of both parties expressed that they owned/advised on properties with a mix of letting structures, including both single occupiers and multi let properties.

The landlords were asked a supplementary question concerning their "Adoption of CSR in the ownership and management of the portfolio"; $80 \%$ stated that they had adopted a CSR policy in relation to their property, whereas the remainder of the respondents either had not adopted such a policy $(7 \%)$ or they did not know if they had one (13\%). This can be considered with reference to the value of the property portfolios where the majority of landlords indicated possession of extremely valuable portfolios. This may suggest that this type of landlord is more likely to have an existing sustainability agenda, including a CSR policy.

\subsection{Awareness of the Act}

Respondents were asked about their 'level of awareness of the Energy Act 2011 and its implications around EPCs' (see Supplementary Appendix B for a table illustrating these results). Although a subjective assessment, $69 \%$ of agents and $77 \%$ of landlords felt they had a 'good' or 'very good' awareness of the Act. The landlords demonstrated a higher degree of awareness than the agents. This point was reinforced by $31 \%$ of agents suggesting they had 'limited' knowledge, compared to $23 \%$ of landlords. None of the participants suggested they were 'unaware' of the Act. When agents were asked if they were 'aware of what property was exempt from the regulations'; 44\% said 'yes', 48\% stated that they 'did not have full awareness' and $8 \%$ said they were 'not aware'. Thus while many were aware of the Act, their knowledge of the details of the Act was not as high. Landlords were asked if they 'had any properties which were exempt from the regulations'; $46 \%$ said 'yes', $41 \%$ said 'no'. It is somewhat surprising to learn that nearly half of the properties are thought to be outside the Regulations. It would be interesting to further explore the nature of these properties and if these opinions are in fact correct. $13 \%$ of landlords ' $d i d$ not know' if they had any properties that would be exempt which could indicate insufficient information on the extent of the exemptions. When asked if the requirements of the Energy Act 2011 in relation to the EPC regulations have been well publicised', 43\% of landlords said 'yes' while only $20 \%$ of agents agreed. The majority of agents (72\%) and $48 \%$ of landlords said 'no', while $8 \%$ and $10 \%$ respectively said they 'did not know'. The results indicate a slight divergence in awareness, with agents seeming less well informed than landlords about the Act.

\subsection{Implications of the Act}

Having establishing the participants' general awareness of the Act, the questioning focused on gathering the parties' perception of the potential implications that the Act could have on commercial property. A number of possible implications were posed (Fig. 1) and respondents were asked to rate the significance of each on a scale from one (being not significant) to five (most significant).

The results in Figure 1 indicate that $70 \%$ of landlord's and $65 \%$ of agents felt that potential 'increased difficulties in selling or leasing properties with low EPCS ratings after 2018' posed a high level of significance; this issue received the highest overall rating of significance from both landlords and agents. Ultimately, if property is not upgraded to achieve an appropriate EPC rating by 2018 landlords could be left with empty property which would not achieve an income return, would incur empty rates liability, suffer from physical deterioration and also face the prospect of declining capital value. Conversely, $6 \%$ of agents thought though this issue was not significant, in contrast to all landlords who perceived it to be of at least some significance. This could be a reflection of the different priorities for each party. For example, landlord's, as property owners, are likely to have more concern for financial aspects that relate to investment return and capital appreciation, whereas it is probable that agents will focus more on letting and marketability. It was also stressed in qualitative comments by one respondent that "a two tier market could emerge with regards to non-prime property". This has also been highlighted in the literature (Reed et al. 2011; Wilkinson 2012). Hinnells et al. (2008) also posit that, over long timescales, poor energy performance 
1 (Not Significant) $\square 2 \square 3 \square 4 \square 5$ (Most Significant)

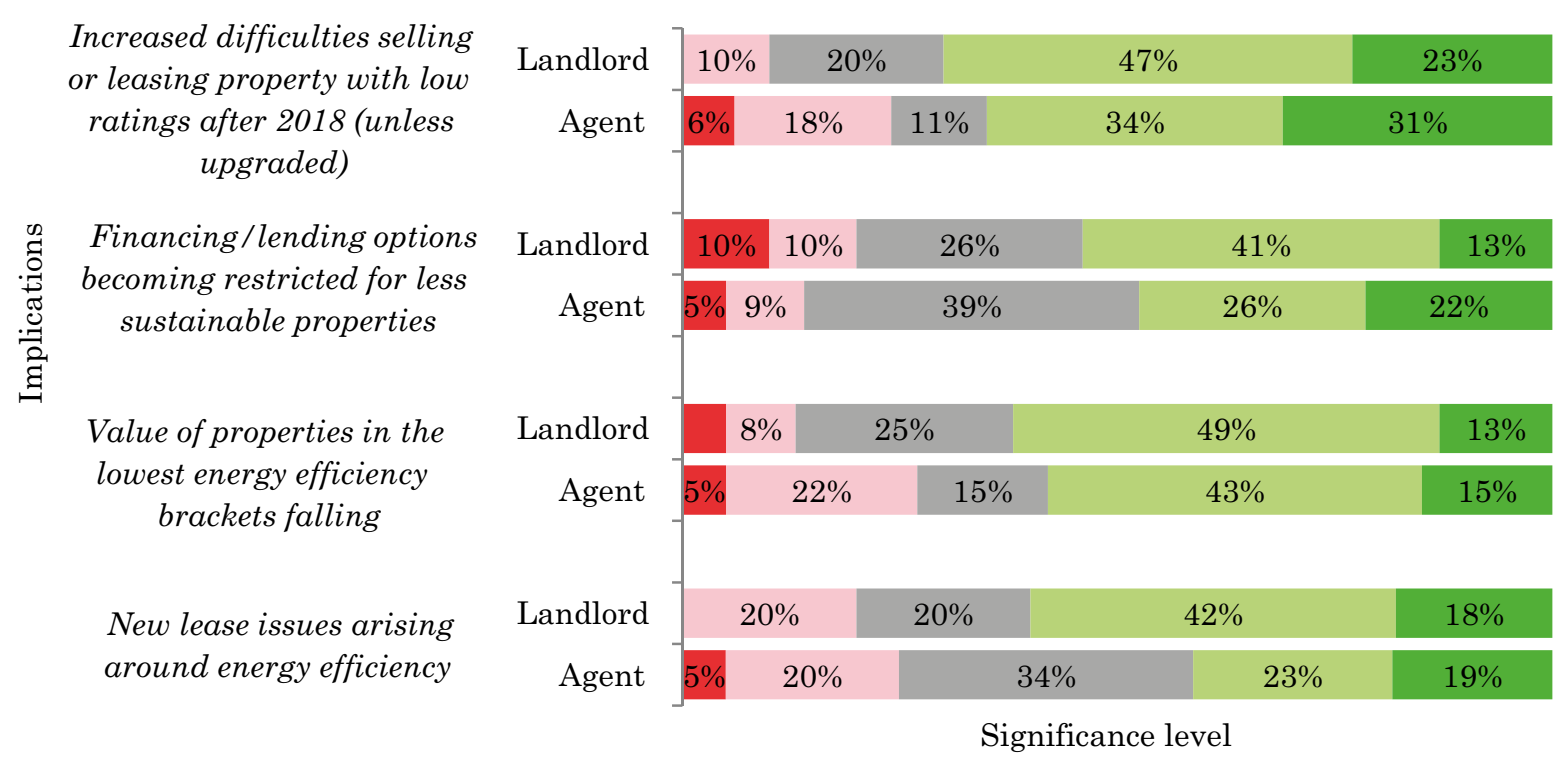

Fig. 1. Potential implications of the Act

is likely to affect the capital value of investment properties. There is an expectation amongst investors that poor energy performance will lead to "price chipping" during rental negotiations (Investment Property Forum 2007). This prospect is heightened by the MEES regulations discussed in this paper. Accordingly respondents were asked to consider the impact the Act may have on property values. Congruently, $62 \%$ of landlords and $58 \%$ of agents placed a high level of significance on the prospect of the 'value of properties in the lowest energy efficiency brackets falling' due to the Act. Although there is a developing body of research on the impact of sustainability on property values (Chegut et al. 2014; Eichholtz et al. 2010; Pivo, Fisher 2010; Fuerst, McAllister 2011; Fuerst et al. 2013), there are still no firmly established findings in the UK (Lown 2014). While price premiums for sustainable property may not be firmly established in the UK the results indicate that there is certainly a concern surrounding the potential for the value of inefficient properties to fall in the near future. Theoretically, if a property fails to reach the required EPC rating by 2018 it could be regarded as having reduced rental value as it could not be legally let until energy efficiency improvements are made; this may then begin to provide evidence of a decline in property values due to sustainability. When valuing property with low EPC ratings, the valuation may have to allow for the cost of improvements if works are likely to be pursued at the property.

Property owners and investors may find that lenders begin asking about the energy efficiency of property and whether the cost of bringing property up to the required standard has been factored in. Landlords and agents held quite consistent views concerning the potential for 'financing and lending options becoming restricted for less sustainable property'; $54 \%$ of landlords and $48 \%$ of agents felt this was a highly significant prospect. $10 \%$ of landlords and fewer agents, 5\%, considered this area to be of no significance to them and their portfolios. Industry research suggests that UK commercial property lenders have a lack of awareness of the potential implications of the Energy Act 2011 (Cushman, Wakefield 2013). This could explain why the parties' concern for this issue was not more significant. However, recent research suggests that some banks are already requesting EPC ratings before lending and, where required, cost estimates to improve the EPC rating (Elliott et al. 2015). This was echoed by one landlord in this study who commented that "a lender would not necessarily decline the opportunity to lend against a non-complaint property but they would probably require the borrower to demonstrate the upgrade proposed on the property and make this a condition of the loan".

It is also likely that the Act will impact on the landlord and tenant and the drafting of new commercial leases. The standard commercial lease, particularly in multi-tenanted buildings, is generally perceived as a barrier to environmental improvement (Langley, Stevenson 2007). The structure of traditional leases and the relatively shortterm nature of a tenant's interest generally mean that neither landlord nor tenant has a financial 
incentive to reduce energy consumption (Hinnells et al. 2008). Accordingly, respondents were probed on their views with regard to "new leasing issues arising around energy efficiency'; $60 \%$ of landlords, but fewer agents (42\%), felt that this prospect was highly significant (Fig. 1). The lower level of significance by agents is somewhat surprising given that they are heavily involved in letting and negotiating leases. Furthermore, it was suggested by agents that lease issues will vary for the different market sectors. For example, one agent suggested that "industrial leases may have few green covenants due to having no heating in units or limited insulation, yet office leases might be quite extensive on energy efficiency covenants". Potential lease issues are considered in more depth in Figure 2.

\subsection{Impact of the Act on commercial lease provisions}

Even in buildings designed for high environmental performance, the manner in which they are occupied and used will significantly affect their environmental performance. For commercial investment property the leasehold relationship, in part, will have a significant impact on the occupation and use of the property. As well as ignoring environmental performance, Hinnells et al. (2008) posit that in many respects traditional commercial leases can actually hinder environmental improvements being made. It is therefore suggested that leases need to be adapted to provide a structure that supports buildings being used and operated in an environmentally efficient way (Hinnells et al. 2008). The relationship between landlord and tenant will thus need to change in order to progress with regards to the energy performance of buildings and sustainability in general. Accordingly, the respondents were asked about their perception of how significant, on a scale of one (not significant) to five (most significant), the Act will be with regard to a number of lease provisions after 2018 (Fig. 2).

Generally dilapidations provisions require tenants to reinstate premises to their former condition at the end of a lease. This is seen to discourage tenants from making energy efficient upgrades (Hinnells et al. 2008). Consequently, it is anticipated that the Act will have an impact on this issue. In conformity between parties, the results indicate that $66 \%$ of landlords and $62 \%$ of agents considered the Act would likely have a highly significant impact on 'dilapidations' post 2018. Similarly, $65 \%$ of landlords and $63 \%$ of agents felt the Act would have a highly significant impact on 'reinstatement at lease end'. As sustainability becomes more prominent on landlords' agendas, some tenants may find that they will be released from the traditional lease obligation to reinstate the premises at lease end if the landlord considers it unnecessary or unsustainable. In terms of alterations clauses, the environmental impact of tenant modifications is not traditionally taken into consideration but it is anticipated that this is likely to change in light of the Act and the sustainability agenda in general. The results indicate that landlords generally placed higher significance on the potential for the Act to impact on tenant's improvements and alterations in comparison to agents; $47 \%$ of agents perceived 'tenant's alterations' to be of high significance in comparison to $66 \%$ of landlords. Similarly, $47 \%$ of agents perceived 'tenant's improvements' to be of high significance in comparison to $62 \%$ of landlords. This divergence may be due to landlords being more closely involved in negotiating on improvements and alterations given that they will consider the impact of such works on the future marketability and any damage to their reversion that may occur. Landlords may begin insisting upon the nature of the improvements and alterations so that any work does not diminish EPC ratings. Lease clauses could provide that it will be deemed reasonable for the landlord to refuse consent if alterations would have a negative impact on the energy performance of a building (Hinnells et al. 2008).

Standard lease clauses are unlikely to allow landlords to pass on the costs of environmental improvements through a service charge (Hinnells et al. 2008). Accordingly, for multi-let properties this is expected to be an area that may witness change. Both parties' views were parallel and fairly inconclusive in relation to the likely impact of the Act on 'service charge provisions' after 2018; $55 \%$ of landlords and $58 \%$ of agents felt this was a highly significant issue (Fig. 2). It was apparent that both parties felt the impact of the Act would be less significant on 'rent reviews', 'consent to assign' and 'consent to sublet' compared with the aforementioned lease covenants which relate to the physical fabric of the property. In particular, agents placed a much lower level of significance on 'consent to assign' and 'consent to sublet' in comparison to landlords. $47 \%$ of landlords thought the impact of the Act on 'consent to assign' would be highly significant and $51 \%$ felt the same about 'consent to sublet'. This can be contrasted with far fewer agents, $21.5 \%$ and $19 \%$ respectively. The Act 


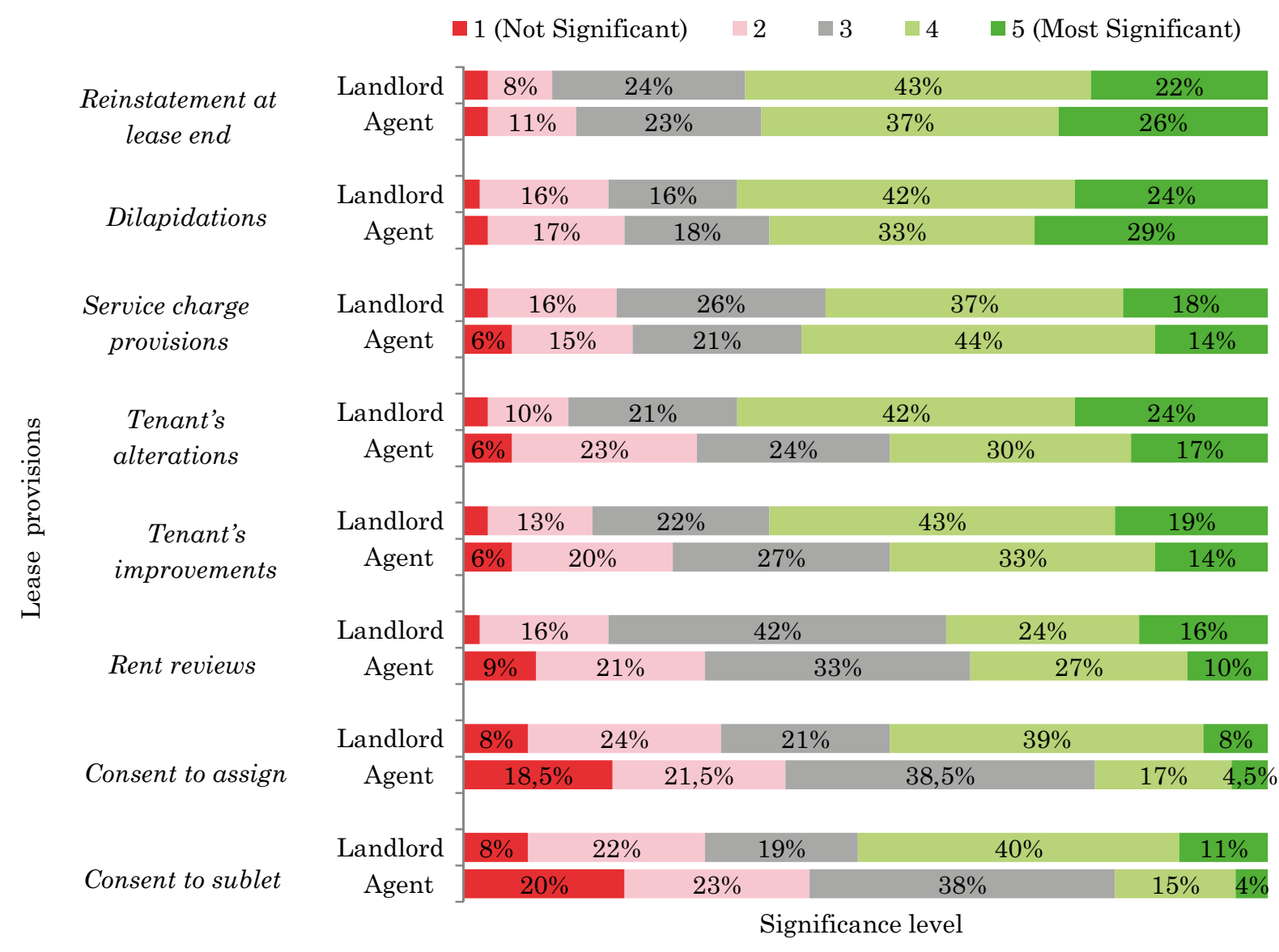

Fig. 2. Impact of the Act on lease provisions

is likely to impact on rent review provisions since they proceed on the basis of a hypothetical letting of the premises with vacant possession, which will require an $\mathrm{EPC}$ of an $\mathrm{E}$ rating or higher (if no exemptions apply) come 2018. Even though an existing lease may not currently be in breach of the Act, it may be assumed for the purposes of the rent review it will become unlawful to let the premises once the Act is implemented in 2018. This could impact on a tenant's ability to assign or sublet the premises after 2018 and, therefore, may affect the rental value. However, only $40 \%$ of landlords and $37 \%$ of agents felt that the Act would have a highly significant impact on 'rent reviews'. For landlords this was the lease issue that they felt was least significant with regard to the Act's impact after 2018. The influence of the Act will ultimately depend upon on the wording of the rent review clause, including what is to be assumed and disregarded.

Overall the results in Figure 2 indicate that, in terms of lease provisions relating to the physical aspect of the property (improvements, alterations and dilapidations), the parties felt that the Act could have serious implications. The contractual relationship between landlord and tenant appears to be less of an issue currently for both parties in comparison to the financial implications derived from the more physical lease terms.

\subsection{Potential preparations for the Act: management and investment decisions}

After gathering perceptions on the implications of the Act, the survey focused on understanding the parties' perception of how the commercial sector could prepare for the implementation of the Act in 2018. Respondents were asked to rate a number of 'actions' that could be undertaken in preparation for 2018 on a scale of importance which ranged from one (not important) to five (most important) (Fig. 3). The results demonstrate that, for landlords, 'proactively thinking about improving energy efficiency when repairing, upgrading, altering property or doing routine maintenance' was viewed as the most important activity in preparation for 2018 ; $82 \%$ of landlord's thought that this activity was highly important, as did $76 \%$ of agents. Overall, this activity was ranked in second place by agents who gave slightly higher emphasis to 'building in costs of necessary statutory work under the Act when buying new property'. In third 
priority for agents and fourth for landlords was 'putting an energy efficiency plan in place where the EPC rating is $F$ or $G$ '; $74.5 \%$ of landlords and $71 \%$ of agents considered that this was of high importance in preparation for 2018. Despite previous research suggesting that poor rated EPCs do not adversely impact on the buying and selling process (Elliott et al. 2015), 79\% of landlords and $65 \%$ of agents in this study considered that it was highly important to 'consider the requirements of the Act and EPC ratings when buying or advising on new investments'. This demonstrates that many landlords, in particular, appear to be seeking to safeguard the future of their portfolio by ensuring that future property acquired will be Act compliant where possible. The results in Figure 3 illustrate that both parties were fairly congruent in terms of their opinion of the importance of using or consulting EPC ratings to assess property. However, there needs to be an element of caution when using EPC ratings because they only indicate an asset's theoretical energy efficiency, rather than actual energy consumption (JLL and BBP 2012). In reality a building's actual energy consumption will be highly influenced by the occupier, despite its design intent. A number of landlords and agents in this survey commented on the usefulness of EPC recommendations and suggested, for example, that "EPCs are usually weak in content and not robust enough to base investment decisions on". It was recommended by one respondent that "a more detailed EPC rating report is required which will provide sufficient depth for decision making", while another stressed that "a different reporting system should be developed for this legislation". Display Energy Certificates (DECs), which are mandatory for public sector buildings, are generally perceived to be of more value since they focus on actual energy consumption. One respondent also commented on inaccuracies in assessments, suggesting that "two assessors undertaking an EPC assessment on the same building can arrive at different assessments". Concern over the limitations and potential for inaccuracies in EPCs is also highlighted in the literature (Elliott et al. 2015; Lown 2014). An additional issue is that EPCs are valid for 10 years. Thus, Lown (2014) suggests that when a building was last certified, along with the quality of the data input at the time, can have a detrimental effect on EPC ratings. Accordingly, the reliability of exiting EPCs should be questioned, particularly if they are being used to base investment decisions on.
The parties diverged in opinion with regard to 'undertaking cost-benefit appraisals to assess financial implications of upgrading buildings and retention/disposal strategy'; $67 \%$ of landlords thought this action was highly important while only $55 \%$ of agents held the same view. This reinforces the observation that landlords are placing more emphasis on considering the longer term financial implications of the regulations than agents. In addition, more landlords (64\%) than agents (53\%) felt it was highly important to 'take advantage of voids/lease breaks to make energy efficiency improvements prior to 2018'. Both parties placed lower levels of importance on the 'use of an asset management strategy to improve operational performance; ; only $54 \%$ of landlords and $42 \%$ of agents felt that this activity was highly important. Similarly, 'considering alternative use or disposal for unviable EPC properties' was rated lower than many other actions; around half of the respondents (49\% of landlords and $52 \%$ of agents) considered this activity to be of high importance.

\subsection{Current preparations: management and investment}

The survey subsequently sought to understand the landlords' current level of preparation for the Act (such questions were thus excluded from the agent survey). To gain an understanding of the extent of risk posed by the Act, landlords will need to gain a full picture of the energy performance of their stock. Accordingly, landlords were asked if they had 'already undertaken EPC assessments on their stock'; the majority ( $82 \%)$ had undertaken EPC assessments on 'all or most of their stock',18\% had undertaken assessments ' $a$ small minority of stock', while no respondents indicated that they had 'not acted on EPCs at all'. Having considered the respondents views on the importance of various actions which could be undertaken in preparation for the Act (see Fig. 3), landlords were then asked to indicate which of these 'actions' they were already 'currently engaged in'. The respondents were asked to indicate whether they were currently engaging in the activity on either: 1) 'all of their stock', 2) 'some of their stock', 3) 'no stock yet, but will be doing so in the near future' or 4) 'not on any stock' (see Supplementary Appendix C for a visual representation of the results). The majority of landlords (85\%) were already 'proactively thinking about improving energy performance when repairing, upgrading, altering or during routine mainte- 
Assessing risk exposure to E-rated buildings (in anticipation of possible future policy)

Building in the cost of necessary works under the Act when buying new property

Considering EPC requirements when thinking about acquiring new property investments

Considering alternative use or disposal for premises which have an unviable solution for improving the EPC rating

Undertaking cost-benefit appraisals to assess financial implications of upgrading buildings and retention/disposal strategy

Taking advantage of voids/lease breaks to make energy efficiency improvements prior to 2018

Proactively thinking about improving energy efficiency when repairing / upgrading/altering/during routine maintenance

Using an asset management strategy to improve operational performance

Where EPC is F or $G$ (or at risk of becoming) putting an Energy Efficiency Plan in place to improve the efficiency of the property

Checking EPC recommendation reports and establishing the cause of any low ratings

Using EPC ratings to assess the energy performance of buildings

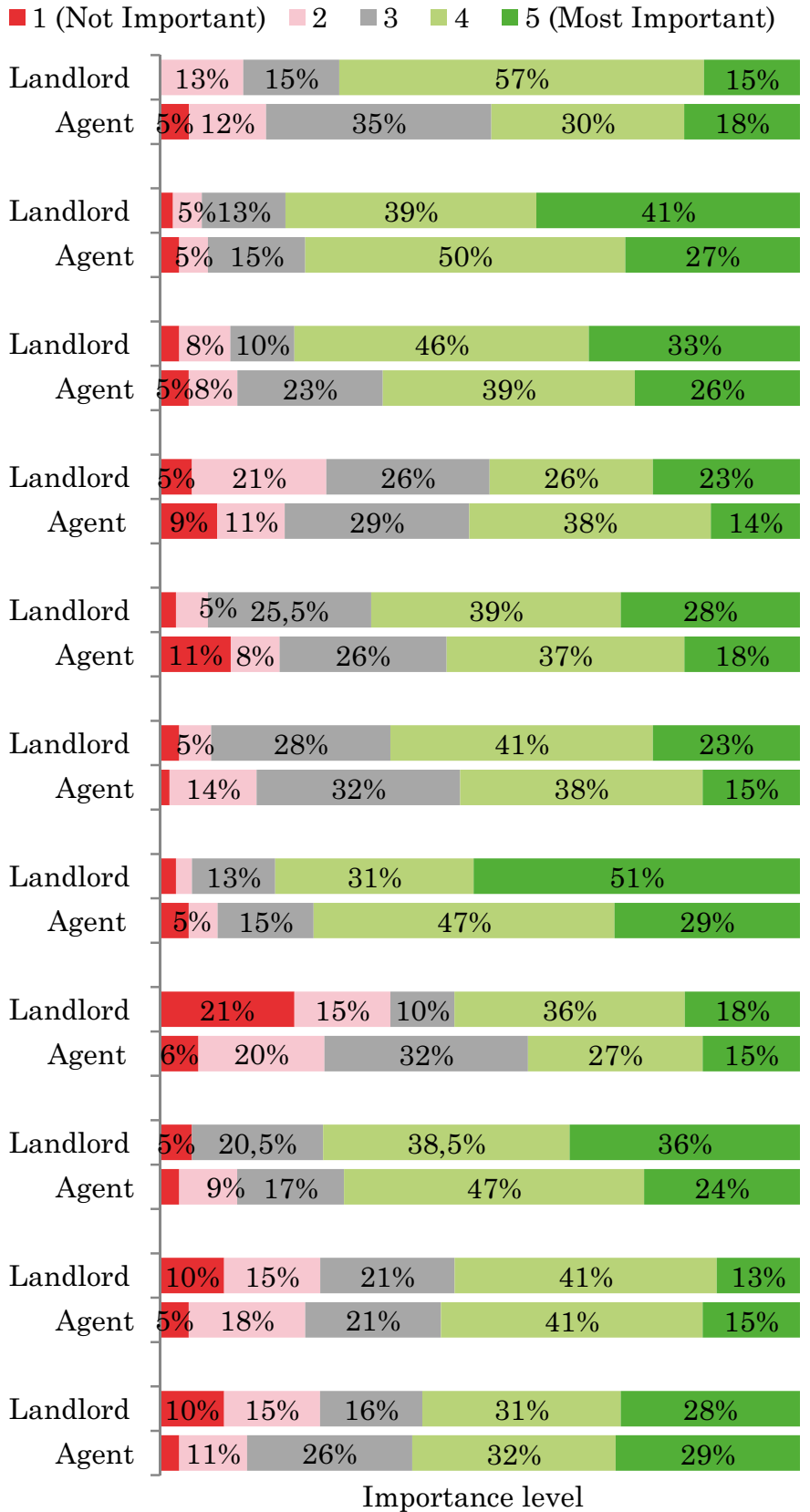

Fig. 3. Potential actions in preparation for the Act nance' for either all or some of their stock. This action was also prioritised as most important by landlords in Figure 3. Given that many respondents were fairly contemptuous regarding the reliability and quality of EPCs, the results indicate that 'using EPCs to assess the energy performance of buildings' was an action that many of the landlords were currently engaged in, with $77 \%$ having done this for at least some or all of their stock. $74 \%$ of landlords were currently 'considering the requirements of the Act with regards to EPC ratings when thinking about acquiring new property'. A further $72 \%$ were already 'checking EPC recommendations and establishing the cause of any low ratings' on all or some of their stock. The data therefore suggests that the majority landlords are actively involved, to some degree, in assessing EPC ratings due to the Act. There are anecdotal signs in the marketplace that the capital expenditure necessary to improve a property's EPC rating is being factored into investment appraisals (Lown 2014). This was confirmed by $65 \%$ of landlords in this study who suggested they were already 'building in the cost of necessary statutory works under the Act when buying new property' (for all or some of their stock). A further $15 \%$ were considering doing so in the near future. Despite being considered less important 
than other actions (Fig. 3), 60\% of landlords were currently 'using an asset management strategy to improve operational performance' and 'taking advantage of voids or lease breaks to make energy efficiency improvements prior to the legislation coming into effect' (for some or all of their stock). $59 \%$ of landlords had also 'put an energy efficiency plan in place to improve the efficiency of property where the EPC was F or G (or at risk)'. A further $57 \%$ of landlords were actively 'assessing risk exposure to ' $E$ ' rated buildings (in anticipation of possible future direction of Government policy)' for some or all of their stock. This demonstrates that there is a degree of uncertainty around the Act, specifically the MEES becoming more stringent. In addition, 53\% of landlords suggested they currently 'undertake cost-benefit appraisals to assess the financial implications of upgrading buildings' for some or all of their stock. A further $27 \%$ of landlords were considering doing so in the near future. Elliott et al. (2015) also found that, when buying commercial property, investors are particularly concerned with understanding the likely cost of bringing property up to the required E rating. Only $35 \%$ of landlords had 'considered alternative use or disposal for premises which have an unviable solution for improving the EPC rating', while $45 \%$ had not yet considered this option for any stock. It is clear from the results that the vast majority of landlords are actively engaged in some aspect of activity on all or some of their stock in preparation for the 2018 deadline. These actions include risk planning, energy saving assessments and a formal management approach required to improve EPC ratings on their stock.

\subsection{Current preparations: lease provisions}

Landlords and agents were subsequently requested to indicate their level of preparation and engagement with a number of 'actions' specifically related to leasing practice (Fig. 4). Landlords were asked to indicate what 'actions they were currently engaging in', while agents were asked to indicate what 'actions they were currently advising their clients to engage in' as preparation for the implementation of the Act in 2018. For each action respondents could indicate one of the following engagement levels: 'yes' (currently engaged in); 'no' (not engaged in); or 'no not engaged in, but will be doing so in the near future'.

The results suggest that landlords were most actively involved in 'encouraging tenants to use energy efficient materials and technology when undertaking any works'; 41\% suggested they al- ready do this currently, but fewer agents (21\%) were advising clients on this. This is in line with Figure 3 where landlords suggested that the most important action in preparation for the Act was 'proactively thinking about improving energy efficiency when repairing, upgrading, altering or during routine maintenance'. The results of this study also indicate that the Act has had some impact on green leasing activity. While there has been much discourse around the topic of green leasing on an international scale (Christensen, Duncan 2007; Hinnells et al. 2008; Oberle, Sloboda 2010), there is little evidence as to what is happening in the marketplace (Roussac, Bright 2012). The results appear to demonstrate that landlords have been more proactive than agents with regard to green leases; $38 \%$ already 'incorporate green covenants in new leases' while $44 \%$ intend to do so in the future. In contrast, only $12 \%$ of agents were currently engaged in this, with a further $27 \%$ intending to do so in the near future. However, agents were not necessarily ignoring the potential need for lease changes. Figure 4 reveals that $18 \%$ of agents were currently advising on the 'introduction of sweeper provisions into service charges to cover for any additional costs relating to environmental works' and $20 \%$ had begun 'making amendments to existing leases to satisfy the requirements of the Act'. However landlords indicated a higher degree of engagement with such activities. Overall, $74 \%$ of landlords were currently (28\%) or considering (46\%) 'making amendments to existing leases to satisfy the requirements of the Act'.

Both parties were participating to a similar degree in the insertion of lease clauses regarding the maintenance of a certain EPC rating. 20\% of landlords and $18 \%$ of agents were currently including 'reinstatement clauses that requires a tenant to return a property with the same EPC rating as at lease outset', with a further $26 \%$ and $40 \%$, respectively, considering doing so in the future. Correspondingly, $18 \%$ of landlords and $20 \%$ of agents had begun 'inserting lease clauses that penalise a tenant if they do not maintain an EPC rating at a specific level'. More agents (23\%) than landlords (15\%) had already begun advising on the inclusion of a service charge clause to allow the landlord to recover some costs of fitting out works necessary to comply with the Act'. Only 13\% of landlords and $17 \%$ of tenants were currently 'incorporating disregards in to rent review clauses', but a further $54 \%$ of landlords and $30 \%$ of agents were considering this for the future. Very few of the participants, $3 \%$ of landlords and $11 \%$ 
Yes $\square$ No, but will be doing so in the near future $\square$ No

If landlord is not doing environmental works, negotiating rent free periods on new lettings to cover period required by tenant to undertake required works

Regear/renegotiating leases prior to 2018 in order to seek to avoid the implications of the Act until a later date

Incorporating a disregard in to rent review clauses

Including a service charge clause to allow the landlord to recover some costs of fitting out works necessary to comply with the Act

Inserting a lease clause that penalises tenants if they do not maintain EPC rating at 稸

Inserting a reinstatement clause that requires tenant to return property with the same EPC rating as at lease outset

Making amendments to existing leases to satisfy the requirements of the Act

Including a sweeper provision within service charge to cover for any additional costs relating to environmental works

Incorporating 'green' covenants in new leases

Encouraging tenants to use materials /technology that would benefit energy efficiency when undertaking any works

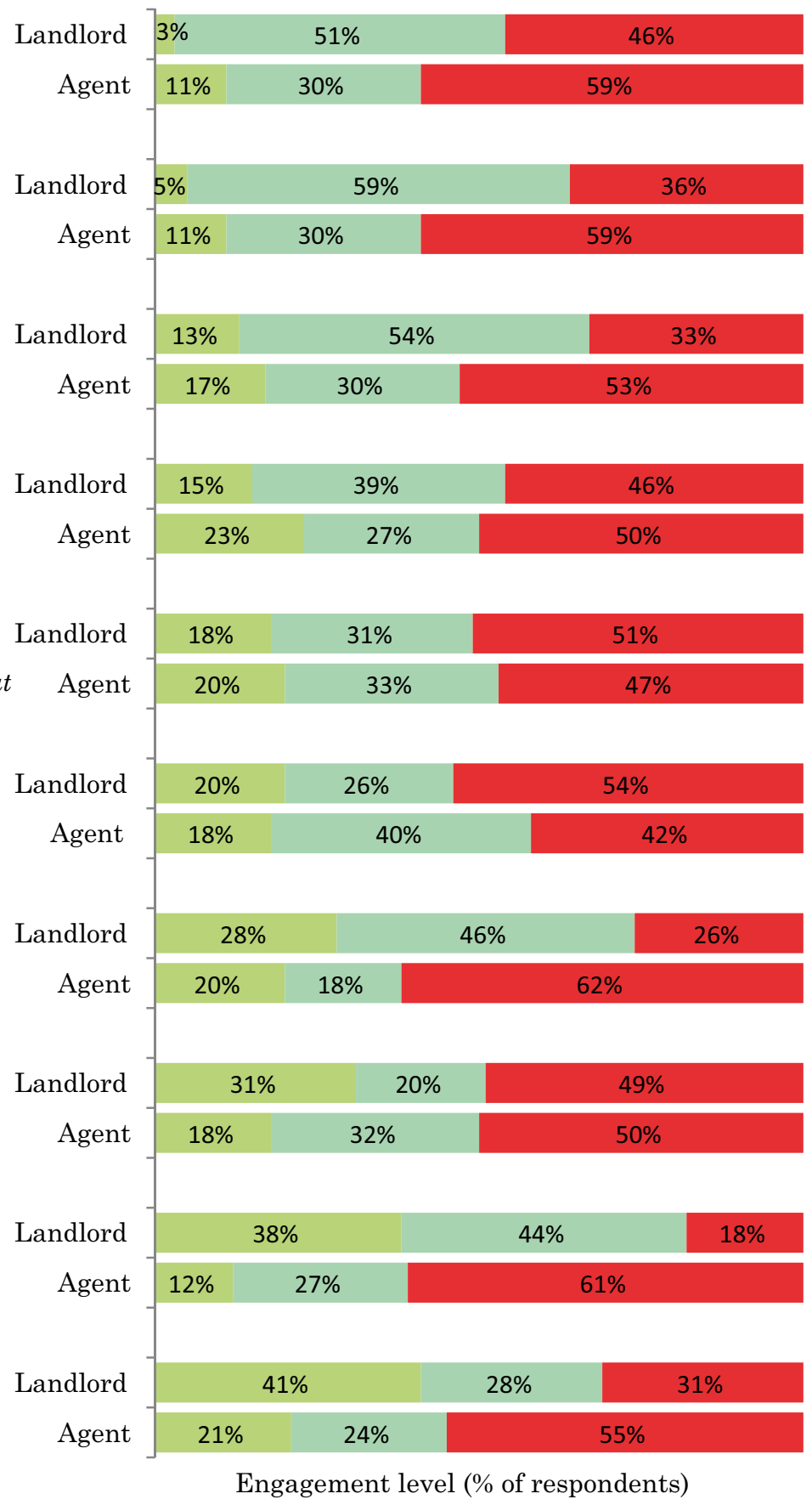

Fig. 4. Lease preparations for the Act

of agents, had begun 'negotiating rent free periods to enable tenants to undertake required EPC works'. In addition, only 5\% of landlords and $11 \%$ of agents were presently in the process of regearing or renegotiating existing leases to seek to avoid the implications of the Act'. Well over half of the agents were not considering the options of rent free periods, using disregards in rent reviews or regearing leases prior to 2018 .
The results indicate that landlords are more pro-active and are currently embarking on, or considering, a broader range of environmental activities to comply with the requirements of the Act. This is not surprising since landlords have a vested interest in the future marketability and value of their property and will likely take a longer term strategic approach. 


\subsection{Interpretations of the Act}

Both parties were finally questioned on their general interpretations of the Act using Likerttype statements on a scale of 'strongly agree' to 'strongly disagree'. Figure 5 illustrates landlords' and agents' general opinions on the impact the Act may have on demand in marketplace. Overall, landlords and agents were fairly congruent in their opinions on the Act and clear concerns for the impact the Act may have on demand for commercial property in the marketplace were illustrated.

Despite the growing body of research - particularly in the USA, UK and Australia - investigating rent and sales price premiums for sustainable buildings (Miller et al. 2008; Eichholtz et al. 2010; Pivo, Fisher 2010; Wiley et al. 2010; Fuerst, McAllister 2011; Reichardt et al. 2012), there is a lack of reliable data to accurately demonstrate that more energy efficient buildings command a higher value or rent in the UK market (Lown 2014). Although robust evidence of a specific premium for sustainability is missing, the results in Figure 5 indicated that many respondents ( $74 \%$ of landlords and $68 \%$ of agents) agreed that 'energy efficient buildings would increasingly have a competitive edge in the marketplace'. The literature suggests that there is increasing demand for sustainable buildings by some corporate occupiers (Dixon et al. 2009; Levy, Peterson 2013). Coinciding with a general view that sustainable buildings will become more competitive, $59 \%$ of landlords and $56 \%$ of agents felt that 'poorly performing buildings (in EPC terms) would be less attractive to owners and occupiers until energy efficiency is addressed'. Furthermore, there is a growing body of evidence suggesting that buildings that have good environmental performance are likely to be future-proofed over time and less susceptible to value depreciation (Sayce et al. 2007). Correspondingly, literature suggests that poorer performing properties, in sustainability terms, could be subject to brown discounts (Lown 2014) and obsolescence in the future (Ellison, Sayce 2006; JLL 2013). Just less than half of the respondents in this study (49\% of landlords and $47 \%$ of agents) were concerned that 'buildings which do not meet at least an 'E' EPC will result in a 'brown discount as we approach 2018'. Fewer landlords (41\%) and agents (44\%) were concerned that 'buildings which do not meet at least an ' $E$ ' grade EPC will face obsolescence' as a result of

$\square$ Strongly Agree $\square$ Agree $\square$ Neither Disagree $\square$ Strongly Disagree

\begin{abstract}
Energy efficient buildings will increasingly have a competitive edge in the marketplace

Many city centres will suffer from vacant sub-standard property which if not demolished/converted will stay on the market for years due to the EPC regulations
\end{abstract}

As we approach 2018, buildings which do not meet at least an ' $E$ ' EPC will result in a 'brown discount'

Buildings which do not meet at least an ' $E$ ' EPC will face obsolescence

\section{Poorly performing buildings (in EPC terms) will be less attractive to owners /occupiers until energy efficiency is addressed}

The requirements of the Act are currently a priority when advising / dealing with commercial property

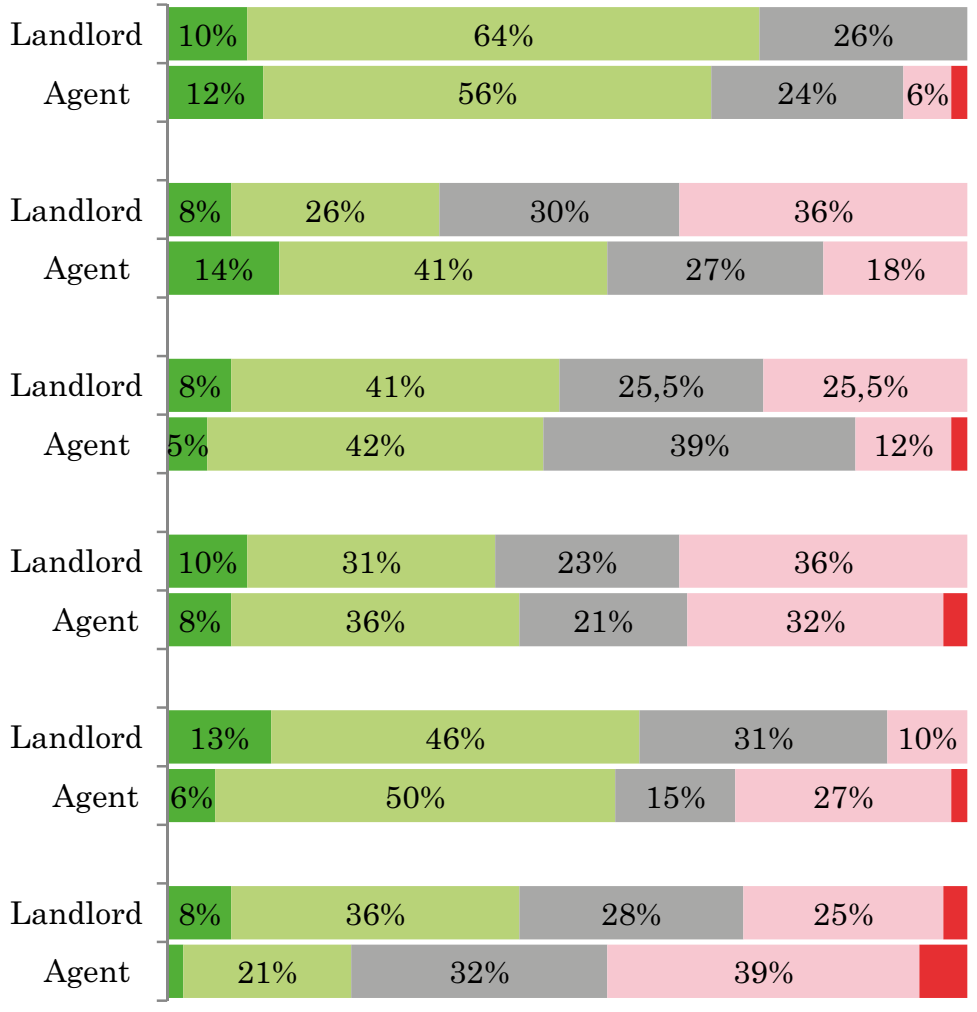

Agreement (\% of respondents)

Fig. 5. Impact of the Act on demand in the market 
the Act. Most disagreement amongst the parties centred on economic life for locations with properties outside of the Act and prioritisation of the Act. Landlords held a majority view that properties outside of the Act may still have an economic life, though agents were less convinced; $34 \%$ of landlords and $55 \%$ of agents agreed that 'many city centres would suffer from vacant and substandard property which if not converted would stay on the market for years'. Far more landlords (44\%) than agents (23\%) suggested that the 'requirements of the Act were currently a priority when advising or dealing with commercial property'. This confirms earlier findings that landlords are generally more concerned and proactive, than agents, with regard to the Act. Though the Act may not currently be a priority for many of the respondents, it is clear that it is being taken into consideration and the impact of the Act is beginning to be felt.

Further landlord and agent opinions were gathered on the workings of the Act in the market place using Likert-type scale statements (see Supplementary Appendix D for a visual representation of the results). The majority of both parties expressed the view that the government has not done enough to help landlords deal with the legislation. Only $13 \%$ of landlords and $3 \%$ of agents agreed the 'government was doing enough to assist commercial landlords with the new legislative requirements'. The results revealed a resounding agreement between the parties, $72 \%$ of landlords and $73 \%$ of agents, that 'empty rates should be reviewed due to the potential impact of the Act on poorly rated buildings'. For example, having an extended period of empty rates relief may provide landlords with an incentive to make energy efficiency improvements during void periods. The results also demonstrated some uncertainty about the way in which the legislation will be implemented in 2018. There was concern that the government may change the legislation prior to 2018; the majority of participants were not convinced that the 'EPC legislation will be introduced in its current definitive form' (only $26 \%$ of landlords and $14 \%$ of agents agreed that this would be the case). More agents (44\%) than landlords (28\%) agreed that the 'EPC legislation may be watered down when it is introduced'. However, both parties (59\% of landlords and $50 \%$ of agents agreed) expressed a greater degree of concern that 'the government could raise the minimum EPC rating above ' $E$ ', in the future'. Such apprehensions are echoed in the literature (Elliott et al. 2015). Despite indications that the Regulations will be enforced by lo- cal Trading Standards Officers, with fines for noncompliance, several respondents ( $64 \%$ of landlords and $77 \%$ of agents) agreed that 'many landlords will continue to let properties after the 2018 deadline which are outside the Act'.

\section{CONCLUSIONS}

The Energy Act 2011 and subsequent minimum energy efficiency standards (MEES) are central to enhancing the energy efficiency of UK buildings, part of wider government policy to reduce the UK's overall carbon emissions. The Act contains a number of significant implications for the commercial property sector. This paper provides a deeper understanding on the impact of the Act and assesses how the commercial sector is preparing for its implementation in 2018, from the perspective of landlords and agents. The paper presents the results of quantitative surveys conducted with over 100 UK commercial landlords and commercial property agents. These findings will be of practical application to property professionals involved in the ownership, investment and management of commercial property.

The research found that there was generally a good awareness of the Act, although agents seemed less well informed than landlords. However the results also indicated that many respondents felt the Government's communication of the Act had been weak. Considering the majority of landlords had some form of CSR policy in place, this may suggest that such participants were more proactive in tracking sustainability related policy and legislation in comparison to agents. 75 additional landlords and agents viewed, but did not complete, the survey. This could suggest that, in hindsight, the survey was too detailed or respondents did not have enough knowledge of the Act to enable them to complete the survey. The implication of this is that the findings may be representative of organisations that have some interest in environmental themes. Moreover, it should be emphasised that, despite attempts to include smaller landlords in the research sample, the results obtained from this study obtained are representative of larger organisations (see 3.1). The authors theorise that the lack of participation by smaller landlords may indicate that such individuals/organisations are less familiar or less concerned with the prospect of the Regulations and have yet to make significant preparations in this regard. Importantly, this may indicate that the Act needs to be better publicised to smaller organisation in particular. 
Although the MEES Regulations do not take effect until April 2018, the results reveal that the impact is already being felt in the commercial sector and is beginning to be considered, to a certain degree, as part of future decision making strategy. In terms of the Act's implications, the result revealed a perception by landlords and agents that the Act could particularly cause increased difficulties in selling or leasing properties with low EPC ratings post 2018, with more efficient buildings thus benefiting from a competitive edge. There is clearly a prospect for a two tier property market to emerge. Concern that the Act could have an impact on property values (with the potential for the value of inefficient properties to fall) was also stressed by more than half of the participants. Regarding the Act's potential impact on leases, the parties generally elicited most concern that it would have a significant impact on covenants that relate to physical fabric of the property, such as reinstatement, dilapidations, alterations and improvements. Yet other covenants surrounding rent reviews, assignment and subletting appeared to be less of a concern for both parties at present.

Preparation for the Act was varied, although the vast majority of landlords were actively engaged in some type of activity (on at least some of their stock) in preparation for 2018 . The results provide evidence that landlords are becoming aware of the sustainability profile of their stock as a result of the Act. For at least some of their stock, many landlords were checking EPCs to assess energy performance and were proactively considering options to improve such performance where necessary. While this may be true for larger landlords/organisations that have the resources to do so (and those which responded in this study), it is likely that smaller landlords who typically only hold only a few properties will be engaging far less, if at all, in any preparations or improvements in order to comply with the Act. The Act is therefore likely to place a much larger burden on, and more adversely affected, the latter come 2018. This could further exasperate the prospect for a two tier property market to emerge. The results also demonstrated that the Act is having some impact on landlords' investment decisions and EPCs are being used as benchmark criteria. Many respondents were beginning to have greater regard for the Act when making acquisition decisions, and the cost of any required works associated with the MEES were being built in. However decisions to dispose of poorly rated stock, particularly with unviable solutions for upgrades, were much less prevalent at present. It is likely that this will increase as 2018 gets nearer. In terms of preparations with regard to lease provisions, many of the respondents were mainly considering making changes to leases in the near future, with fewer having actually already done so. There was generally a greater degree of preparation by landlords than by agents, which was not surprising since the latter are likely to take a longer term strategic approach in their role as owner. Current preparations by landlords primarily concerned the inclusion of green lease covenants and specifying the nature of tenant improvement works so that they enhance, rather than detract from, energy efficiency. If not already amending exiting leases as a result of the Act, the majority of landlords were considering doing so in the near future.

The Regulations are admittedly a complex and evolving area of law. Despite positive evidence of some preparations for the Act being made, there was a strong sense of uncertainty surrounding the Regulations. There is the possibility that the MEES will increase above an 'E' EPC rating in the future and that the methodology for assessment may be revised and become more stringent. Imposing increasing minimum energy ratings on rental properties, while permitting low ratings to remain in owner occupied stock, may contribute further to the creation of a two tier property market; this may have the potential to force landlords, particularly smaller organisations, to withdraw from the investment market due to the cost of compliance with the Regulations. The majority of the participants were unconvinced that the Regulations would be introduced in their current form and there was a perception that many landlords would continue to let unlawful properties post 2018. Such doubt is likely to weaken the confidence of owners and investors and further highlights the need for the Regulations to be better publicised and communicated to key stakeholders. Furthermore, there was particular concern raised by both landlords and agents concerning the utility of EPCs as the measurement tool for the legislation. The authors echo others (Elliott et al. 2015; JLL and BBP 2012) and call for DECs, which focus on actual energy consumption, to be mandated for all commercial property.

Although there is uncertainty surrounding the Regulations, it is vital that the commercial property sector - whether it be owners, investors, occupiers, lenders or advisers - begin considering the possible implications of the Act. The implementation of the MEES legislation is currently less than two years away. Accordingly, there is only a short 
time frame for property owners to seek to minimise the risk of being caught by the legislation and protect asset values. For property owners with assets caught by the Act it could impact on their rental income stream, extend void periods and require capital expenditure. Forward planning and risk management will thus be crucial to maintain investment values. Landlords of all sizes should now, at least, be reviewing their property portfolios to assess the current energy performance of their assets and establish the extent of their exposure to $\mathrm{F}$ and $\mathrm{G}$ rated properties. Where necessary, they should be considering mitigating actions, such as options for improving poor energy efficiency ratings prior to the implementation of the Act or disposing of poorly rated stock. Existing leases will also need to be reviewed to determine liability for bringing poorly rated properties up to standard, while new leases should consider building in covenants that specifically consider energy efficiency. In seeking to discover the commercial sectors' level of preparation for the Act, the survey posed a number of potential actions that could be undertaken prior to its implementation. The range of actions presented in Figure 3 and 4 could be utilised by stakeholders, namely commercial property owners, investors and advisers, as a guide to prepare for the implementation of the legislation in 2018.

Notwithstanding the centrality of the Act to reducing carbon emissions in the built environment, there is much work remaining to achieve significant reductions in the UK's existing built stock. Since the Act only focuses on very poorly performing rented properties, there is still a need to tackle the $80 \%$ of existing commercial rented stock which has energy efficiency bands of $\mathrm{E}$ and above, along with the owner occupied stock which is not caught by the legislation. As previously highlighted, permitting low energy ratings in owner occupied stock but imposing minimum ratings on rental properties may contribute to a two tier property market. Moreover, to seek to reduce carbon emissions it will also be imperative that building management and user behaviour are paid more attention in order to achieve genuine reductions in energy consumption across the built environment.

\section{REFERENCES}

Cargan, L. 2007. Doing social research. Baltimore MD: Rowman and Littlefield.

Chegut, A.; Eichholtz, P.; Kok, N. 2014. Supply, demand and the value of green buildings, Urban Studies 51(1): 22-43. https://doi.org/10.1177/0042098013484526
Christensen, S.; Duncan, W. 2007. Green leases: a new era in landlord and tenant co-operation?, Australian Property Law Journal 15(1): 54-65.

Cox, J.; Cadman, D. 2000. Commercial property markets in a sustainable economy. School of Public Policy and Jackson Environment Institute, UCL, London.

Cushman and Wakefield. 2013. The Energy Act 2011 are lenders switched on to it? [online]. Available at: http://www.cushmanwakefield.co.uk/en-gb/researchand-insight/2013/energy-act-2011-lenders-survey/ [accessed 14 January 2015].

DECC. 2014. Private rented sector minimum energy efficiency standard regulations (Non-Domestic) (England and Wales): Consultation on implementation of the Energy Act 2011 provision for energy efficiency regulation of the non-domestic private rented sector. Department of Energy and Climate Change (DECC). London: Department of Energy and Climate Change.

Dixon, T.; Britnell, J.; Butina-Watson, G. 2014. 'Citywide' or 'City-blind?' an analysis of emergent retrofit practices in the UK commercial property sector, Retrofit 2050, Project report, EPSRC, Cardiff.

Dixon, T.; Ennis-Reynolds, G.; Roberts, C.; Sims, S. 2009. Is there a demand for sustainable offices? An analysis of UK business occupier moves (2006-2008), Journal of Property Research 26(1): 61-85. https://doi.org/10.1080/09599910903290052

Eichholtz, P.; Kok, N.; Quigley, J. M. 2010. Doing well by doing good? Green office buildings, American Economic Review 100(5): 2492-2509.

https://doi.org/10.1257/aer.100.5.2492

Elliott, B.; Bull, R.; Mallaburn, P. 2015. A new lease of life? Investigating UK property investor attitudes to low carbon investment decisions in commercial buildings, Energy Efficiency 8(4): 667-680. https://doi.org/10.1007/s12053-014-9314-2

Ellison, L.; Sayce, S. 2006. The sustainable property appraisal project. Kingston upon Thames, UK: Kingston University.

Estates Gazette. 2014. Landlords face £29bn green refurb bill [online]. Estates Gazette. Available at: http://www.egi.co.uk/news/landlords-face-29bngreen-refurb-bill/ [accessed 16 June 2014].

European Parliament and Council of the European Union. 2010. The Directive 2010/31/EU of the European Parliament and of the Council of 19 May 2010 on the energy performance of buildings [online]. Official Journal of the European Union, 53. Available at: http://eur-lex.europa.eu/LexUriServ/LexUriServ. do?uri=OJ:L:2010:153:0013:0035:EN:PDF [accessed 16 October 2014].

Fuerst, F.; McAllister, P. 2011. Green noise or green value? Measuring the effects of environmental certification on office values, Real Estate Economics 39(1): 4569. https://doi.org/10.1111/j.1540-6229.2010.00286.x

Fuerst, F.; van de Wetering, J.; Wyatt, P. 2013. Is intrinsic energy efficiency reflected in the pricing of office leases?, Building Research and Information 41(4): 373-383.

https://doi.org/10.1080/09613218.2013.780229

GVA. 2014. 2018 EPC minimum standards update [online]. Available at: www.gva.co.uk/sustainability/2018- 
epc-minimum-standards-update [accessed 24 September 2014].

Hinnells, M.; Bright, S.; Langley, A.; Woodford, L.; Schiellerup, P.; Bosteels, T. 2008. The greening of commercial leases, Journal of Property Investment and Finance 26(6): 941-991.

https://doi.org/10.1108/14635780810908389

HM Government. 2011a. The Energy Act 2011. Chapter 16 [online]. London: The Stationery Office. Available at: hhttp://www.legislation.gov.uk/ukpga/2011/16/ contents/enacted [accessed 10 November 2014].

HM Government. 2011b. The Carbon Plan: delivering our low carbon future. London: HM Government.

Investment Property Forum. 2007. The Energy Performance of Buildings Directive: a situation review. London: Investment Property Forum.

JLL and BBP. 2012. A tale of two buildings [online]. Jones Lang LaSalle (JLL) and Better Building Partnership (BBP). Available at: http://www.jll.co.uk/ united-kingdom/en-gb/Research/JLL_BBP_tale_of_ two_buildings.pdf [accessed 18 October 2014].

JLL. 2013. From obsolescence to resilience; creating value through strategic refurbishment and asset management [online]. Jones Lang LaSalle (JLL). Available at: http://www.jll.co.uk/united-kingdom/en-gb/pages/ obsolescence-to-resilience-research.aspx [accessed 18 October 2014].

Langley, A.; Stevenson, V. 2007. Incorporating environmental best practice into commercial tenant lease agreements: good practice guide - Part 1. Cardiff: Welsh School of Architecture.

Levy, D.; Peterson, G. 2013. The effect of sustainability on commercial occupiers' building choice, Journal of Property Investment and Finance 31(3): 267-284. https://doi.org/10.1108/14635781311322238

Lown, M. 2014. Energy efficiency of buildings: the business case, Journal of Building Survey, Appraisal \& Valuation 3(3): 198-205.

Miller, N.; Spivey, J.; Florance, A. 2008. Does green pay off?, Journal of Real Estate Portfolio Management 14(4): 385-399.

Oberle, K.; Sloboda, M. 2010. The impact of 'greening' your commercial lease, Real Estate Issues 35(1): $32-41$.

Pivo, G.; Fisher, J. D. 2010. Income, value, and returns in socially responsible office properties, Journal of Real Estate Research 32(3): 243-270.
Pivo, G.; McNamara, P. 2005. Responsible property investing, International Real Estate Review 8(1): 26-42.

Property Industry Alliance. 2013. Property data report 2013 [online]. Property Industry Alliance. Available at: http://www.bpf.org.uk/en/search_results.php?q=P roperty+Industry+Alliance+\%282013\%29+Property+ Data+Report+2013\&x=13\&y=9 [accessed 19 November 2014].

Reed, R. G.; Wilkinson, S. J.; Warren-Myers, G. 2011. Energy efficiency and property values: a discussion paper, in $17^{\text {th }}$ PRRES Pacific Rim Real Estate Society Conference, 16-19 January 2011, Gold Coast, Australia.

Reichardt, A.; Fuerst, F.; Rottke, N. B.; Zietz, J. 2012. Sustainable building certification and the rent premium: a panel data approach, Journal of Real Estate Research 34: 99-126.

Roussac, A. C.; Bright, S. 2012. Improving environmental performance through innovative commercial leasing, International Journal of Law in the Built Environment 4(1): 6-22.

https://doi.org/10.1108/17561451211211714

Sayce, S.; Ellison, L.; Parnell, P. 2007. Understanding investment drivers for UK sustainable property, Building Research and Information 35(6): 629-643. https://doi.org/10.1080/09613210701559515

Segro and CoreNet. 2013. Energy Act 2011: Implications for occupiers [online]. Segro and CoreNet. Available at: http://higherlogicdownload.s3.amazonaws. com/CORENETGLOBAL/287e1a80-5508-428a85bd-d8b80bb2403e/UploadedImages/Event\%20Reports/2013/16942_SEGRO_Corporate_Energy_Report_v5a_SPREADS.pdf [accessed 19 November 2014].

Stafford, A.; Gorse, C.; Shao, L. 2011. The retrofit challenge: delivering low carbon buildings. York: Centre for Low Carbon Futures.

UK Parliament. 2008. Climate Change Act 2008. Chapter 27 [online]. London: The Stationery Office. Available at: http://www.opsi.gov.uk/acts/acts2008/pdf/ukpga_20080027_en.pdf [accessed 10 November 2014].

Wiley, J. A.; Benefield, J. D.; Johnson, K. 2010. Green design and the market for commercial office space, Journal of Real Estate Finance and Economics 41: 228-243. https://doi.org/10.1007/s11146-008-9142-2

Wilkinson, S. 2012. Analysing sustainable retrofit potential in premium office buildings, Structural Survey 30(5): 398-410. https://doi.org/10.1108/02630801211288189 